Gabriela Matos (2009) Appositive Sentences and the Structure(s) of Coordination. Romance Languages and Linguistic Theory 2006, edited by Danièle Torck and W. Leo Wetzels. Amsterdam/Philadelphia: John Benjamins Publishing Company, $159-173$

\title{
APPOSITIVE SENTENCES AND THE STRUCTURE(S) OF COORDINATION*
}

\author{
GABRIELA MATOS \\ Universidade de Lisboa / CLUL
}

\begin{abstract}
Coordination is not a unitary phenomenon: as far as binding and scope of external elements are concerned, appositive coordinate sentences may differ from their nonappositive integrated counterparts in the same way as appositive relatives differ from restrictive relatives, suggesting that different configurations are involved in appositive vs. non-appositive sentences. The Set-Merge (Kayne 1994) and Pair Merge (Munn 1992) proposals for dealing with coordination, although relevant, are not enough to distinguish appositive from non-appositive sentences. The crucial distinguishing property of appositives is their parenthetical status: they are adjuncts affected by a feature specifying their parenthetical nature. This allows the computational system, which operates bottom up and according to an Earliness Condition (Pesetsky 1989, Chomsky 2001), to interpret them as autonomous CP phases, to be transferred to the Interface components before the phases they are inserted in, thus preventing c-command effects from external elements at SEM.
\end{abstract}

\section{Appositive vs. non-appositive sentences}

Although several studies have pointed out that apposition and coordination are two different phenomena (Quirk et al. 1985, Huddleston et al. 2002, ${ }^{1}$ a.o.), most of the properties of appositive relative sentences have often been attributed to the

\footnotetext{
* I acknowledge the audience of Going Romance 2006 for valuable comments. I am also indebted to two anonymous reviewers, whose remarks and suggestions greatly improve this paper. This paper was developed within Onset-CEL (POCTI-SFA-17-745).

${ }^{1}$ Quirk et al. 1985 define apposition in a broad and in a strict sense. In the former sense, apposition obtains when the apposed expression plays the role of definer of the related NP, as in non-restrictive relatives (the company commander, who is Captain Madison,...), or in non integrated coordination (Fred - or Ginger as he is usually called - ...; You could cut the atmosphere with a knife, and a blunt knife at that). In a strict sense, it is a relation between two NPs identical in reference (Anna, my best friend, ...), or related by inclusive reference $(A$ neighbour, Fred Brick, ...). The authors make a distinction between apposition and appended and interpolated coordination (John writes extremely well - and Sally too; John - and Sally too writes extremely well), which they assume requires ellipsis. In contrast, Huddlestone et al. 2002 admit that apposition is a case of supplementation, which they characterise as interpolation or appendage. In this paper, I will only take into account cases of appositive coordination that may correspond to the broad sense of apposition in Quirk et al. 1985. Besides, I will restrict the analysis to sentence apposition.
} 
existence of a coordinate structure in a step of their syntactic derivation (e.g. Ross 1967, Emonds 1979, Koster 2000, De Vries 2006, a.o.).

Within the Minimalist framework, elaborating on work by Sturm (1986) and Koster (2000), De Vries (2006) assumes that appositions instantiate a third class of coordination on a par with conjunction and disjunction, which denotes specification. In specifying coordination, the two conjuncts refer to a single individual and the second conjunct adds extra information about the entity denoted by the first one. Considering appositive relatives, De Vries claims that they exhibit DP coordination: the first conjunct plays the role of the antecedent of the relative and the second one includes a false free relative, as in (1).

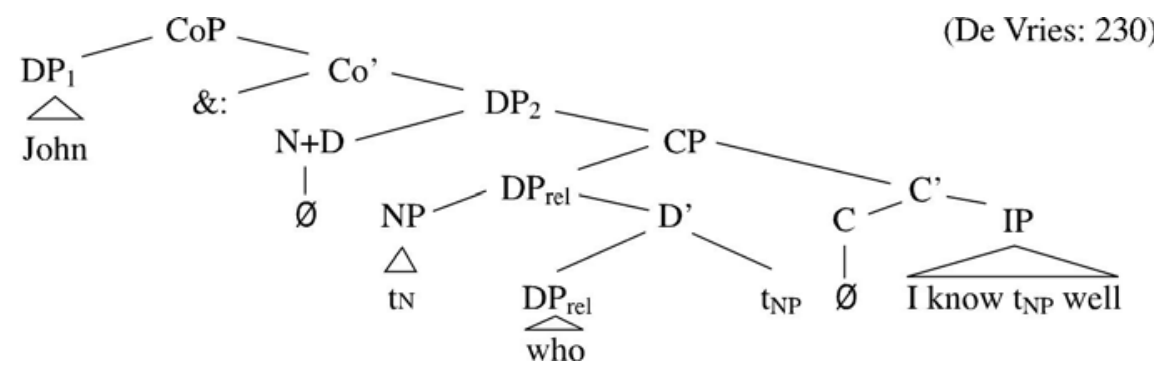

Underlying this approach is the idea that the presence of coordination is the distinguishing property between appositive and restrictive relatives, which accounts for their different behaviour concerning scope and binding effects, as illustrated by examples like (2), from De Vries (2006:234).

(2) a. All the lecturers that passed the test.

b. All the lecturers, who passed the test.

In (2a) 'all the' takes scope over the noun and the restrictive relative; hence, (2a) implies that there is a group of lecturers that did not pass the test". In contrast, in (2b), 'all the' does not take scope over the appositive relative and the conveyed meaning is that "all the lecturers passed the test."

However, taking into account the data of Portuguese, an analysis of relative and coordinate sentences shows that both constructions exhibit appositive and non-appositive counterparts - contrast the non-appositive relative and coordinate sentences in (3), with the appositive ones in (4).
a. As crianças que não dormem
ficam
rabugentas. the children that not sleep-IND.PST.3.PL get-IND.PST.3.PL moody 'The children that do not sleep get moody.'
b. As crianças não dormem
e ficam rabugentas. the children not sleep-IND.PST.3.PL and get-IND-PST.3.PL moody 'The children do not sleep and they get moody.' 
(4)

a. O Pedro, que dorme
the Pedro, who sleep-IND.PRS.3.SG $\begin{aligned} & \text { muito pouco, nunca } \\ & \text { very little, never }\end{aligned}$
está
be-IND.PRS.3SG tired
'Pedro, who hardly sleeps, is never tired.'
b. $O$ Pedro, e ele dorme
The Pedro, and he sleep-PRS.3SG very little, never
está $\quad$ cansado.
be-IND.PRS.3SG tired
'Pedro, and he hardly sleeps, is never tired.'

Besides, as far as scope and binding of external constituents are concerned, the behaviour of appositive vs. integrated coordinate sentences differs, paralleling the contrasts of appositive vs. restrictive relative clauses. Thus, as it is well known (e.g., Safir 1986, Alexiadou et al. 2000, Brito 2005, a.o.), a quantified antecedent may license a bound pronoun inside a restrictive relative clause, as in (5a), but not inside an appositive one, as in $(5 b){ }^{2}$
a. Toda a mulher ama
um homen que every woman love-IND.PRS.3.SG a man that confie $n\left[\right.$ ela $a_{i}$.
trust-SBJ.PRS.3SG in her
'Every woman loves a man who trusts her.'
b. *Toda a mulher gosta do João, que every woman like-IND.PRS.3.SG of the João, who confia $n\left[e l a_{i}\right]$. trust-IND.PRS.3SG in her.
'Every woman likes João, who trusts her.'

The same contrast occurs in sentence coordination: in non-appositive coordination a quantified subject c-commanding the second conjunct licenses a bound pronoun inside this one, see (6a). Yet, this is not possible in an appositive coordinate sentence, see $(6 b){ }^{3}$

\footnotetext{
${ }^{2}$ The relative clause examples for Portuguese have been taken or adapted from Brito 2005 .

${ }^{3}$ A reviewer finds the example in (i), where the coordinate sentence occurs in final position, more acceptable than (6b). He also notes that this sentence may assume an adversative meaning:

(i)?? Todo o homem está por vezes deprimido, e uma mulher confia nele every man be-IND.PST.3SG sometimes depressed, and a women trusts in him 'Every man is sometimes depressed and a women trusts him.'

Notice that in (i), as in (6b), the bound pronoun reading of (n)ele and non-specific interpretation of uma mulher are blocked. However, (i) differs from (6b) by the fact that the non-integrated sentence, e uma mulher confia nele, does not constitute an apposition to the quantified subject todo o homem, being, instead, related to the sentence todo o homem está por vezes deprimido. The adversative flavour of this sentence is a consequence of the contrast that can be established between the meaning of this sentence and the implied content of the sentence it is related to (if a man is depressed, one may not trust him).
} 
(6)
a. Toda a mulher ama every woman love-IND.PRS.3.SG confia em si $i_{i}$ própria.
um homem $e$ trust-IND.PRS.3SG in herself
'Every woman loves a man and trusts herself.'
b. *Todo o homem, e uma mulher confia every man, and a woman trust-IND.PRS.3.SG nele $_{i}$, está por vezes deprimido. in him, is sometimes depressed 'Every man, and a woman trusts him, is sometimes depressed.'

Similarly, a c-commanding negative constituent in the antecedent of a restrictive relative or in the first conjunct of a non-appositive coordinate sentence may set the negative value of an underspecified polarity item occurring inside these non-appositive clauses, as in (7a) and (8a). But this does not occur when appositive relative or coordinate sentences are involved; see (7b) and (8b):
a. Ele não encontrou
um amigo que tenha
feito
he not find-IND.PST.3SG a friend that have.SBJ.3.SG made
qualquer esforço para o ver.
any effort for him see
'He has not found a friend who has made any effort to see him.'
b. *Ele não encontrou o João, que fez
he not find-IND.PST.3.SG the João who make-IND.PST.3.SG
qualquer esforço para o ver.
any effort for him see

'He has not found João, who made no effort to see him.'
a. Nenhum irmão
o procurou
ou um só amigo
no brother him look find-IND.PST.3.SG for or a single friend
$\mathrm{fez} \quad$ qualquer esforço nesse sentido.
make-IND.PST.3.SG any effort in that sense
'None of his brothers looked for him nor did any of his friends make any effort in that sense.'
b. *Nenhum irmão, ou um só amigo fez no brother, or a single friend make-IND. PST.3.SG any
esforço nesse sentido, o procurou.
effort in that sense, him look-IND. PST.3.SG for
'None of his brothers, nor any friend made any effort in that sense, looked for him.'

Likewise, in contrast to what happens to restrictive relatives or non-appositive coordinate clauses, appositive relative and coordinate sentences block Principle C violation effects, as shown in (9) vs. (10). 
(9)

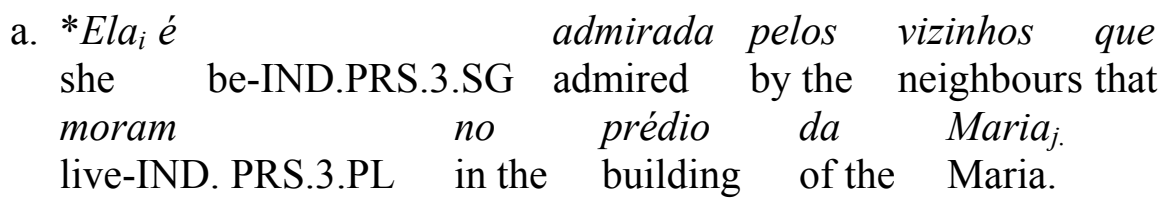

'She is admired by the neighbours that live in Maria's building.'

b. Ela $e_{i}$ é admirada pelos amigos, que she be-IND.PRS.3.SG admired by the friends, who consideram a Maria $_{i}$ uma pessoa encantadora ${ }_{i}$ consider-IND.PRS.3.PL the Maria a person charming. 'She is admired by her friends, who consider Maria a charming person.'
a. ${ }^{*}$ Ela $_{i}$ e a filha da Maria ${ }_{i}$ são as she and the daughter of the Maria be-IND.PRS.3.PL the minhas melhores amigas my best friends.
'She and Mary's daughter are my best friends.'
b. Acho que ela ${ }_{i}$ e a Maria $_{i}$ é think-IND.PRS.1SG that she, and the Maria be-IND.PRS.3.SG a minha melhor amiga, é uma pessoa encantadora. the my best friend, be-PRS.3.SG a person charming. 'I think that she, and Mary is my best friend, is a charming person.'

In sum, restrictive relatives and non-appositive coordinate sentences behave alike. Similarly, appositive relatives and appositive coordinate sentences show identical behaviour: while the former allow for a c-commanding constituent to take scope over and to bind some element inside them, the latter block these scope and binding effects.

\section{Syntactic representations of coordination}

Within the Principles and Parameters framework, the syntax of coordination has been at the centre of a debate where two main proposals focussing integrated coordination emerged: the Specifier-head-complement hypothesis, (11a), adopted by Kayne (1994) and Johannessen (1998), and the Adjunct hypothesis, (11b), proposed by Munn $(1992,1993)$ :

(11) a. Specifier-head-complement hypothesis:

b. Adjunct hypothesis:

[ConjP XP [Conj' [Conj] YP $]$
$[\mathrm{XP} \text { XP [ConjP Conj YP] }]^{4}$

Both of these proposals may be accommodated within the Minimalist Program without any proviso: the Specifier-head-complement configuration derives from Set Merge, and the Adjunct hypothesis results from Pair-Merge, for the adjunct configuration, and from Set Merge for the building up of the ConjP structure.

\footnotetext{
${ }^{4}$ ConjP $=$ BP (Boolean Phrase), in Munn (1992, 1993, 1999).
} 
These analyses differ in the degree of syntactic cohesion that the related constituents exhibit with respect to each other: in the Specifier-head-complement hypothesis, each constituent constitutes a conjunct that is selected as an argument by Conj; in contrast, for the Adjunct hypothesis, the constituent that is interpreted as the first conjunct, is excluded from the ConjP that adjoins to it.

In the remainder of this paper, I will try to show that these hypotheses are not alternative approaches to account for the scope and binding effects in integrated and appositive coordination, and that the distinct behaviour exhibited by these structures partially relies on their different syntactic configurations. ${ }^{5}$

\section{The Set-Merge approach to coordination and the c-command effects}

De Vries (2006) extended the Specifier-head-complement representation to specifying coordination, the type of coordination that he assumes to underlie appositive sentences.

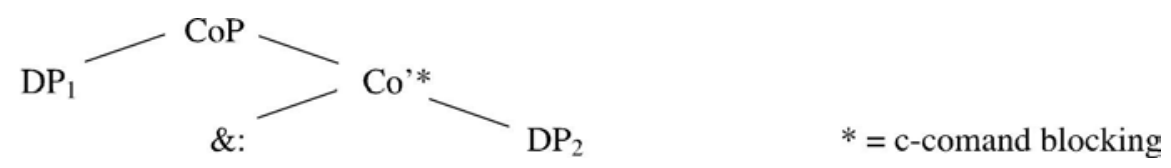

To account for the blocking of c-command in appositive sentences, De Vries (2006) admits that the conjuncts do not c-command each other. ${ }^{6}$ Yet, given the structure adopted (see (12)), c-command of $\mathrm{DP}_{1}$ over $\mathrm{Co}(\mathrm{nj})$ and $\mathrm{DP}_{2}$ should obtain. To prevent this situation, De Vries claims that a special device operates in coordination, b(ehindance)-Merge, defined as an inclusion relation that blocks ccommand.

However, this proposal is challenged not only because b-Merge seems to be a device with no independent motivation, but also because empirical evidence shows that there are coordinate structures, where the first conjunct asymmetrically c-commands the other (cf. Munn 1993 and Kayne 1994) - this is the case of integrated coordination, as illustrated by the example in (13):

(13) a. John ${ }_{\mathrm{i}}$ 's dog and he $\mathrm{i}_{\mathrm{i}} / \mathrm{him}_{\mathrm{i}}$ went for a walk.

(Munn 1993:16)

b. ${ }^{*} \mathrm{He}_{\mathrm{i}}$ and $\mathrm{John}_{\mathrm{i}}$ 's dog went for a walk.

In fact, assuming the Specifier-head-complement hypothesis and an adequate characterization of Conj, it is possible to account for the cases of non-appositive coordination, where the first conjunct takes scope over the second one.

\footnotetext{
${ }^{5}$ Huddlestone et al 2002 assign different syntactic representations to integrated and supplementary sentences. I will not adopt their analysis for reasons that will become clear in section 4.

${ }^{6}$ De Vries illustrates the lack of c-command between the conjuncts in a coordinate structure with a case of local anaphora in Dutch. In this example zichzelf is not bound.

(i) *een gesprek tussen Joop en zichzelf (De Vries 2006: 242)

a conversation between Joop and se-self.
} 
Conj is a functional head that does not impose any restriction on the categorial nature of its arguments ${ }^{7}$ and behaves like a transparent category. Thus, in (14) the verb disregards ConjP and selects its complement based on the categorial nature of the conjuncts - gostar 'like' selects PP, not DP:

Eles gostam $\{[P P$ da familia $e$ dos amigos]
They like-IND.PRS.3.PL of the family and of the friends
$/ *[D P a$ familia $e$ os amigos $]\}$.
the family and the friends

In other words, Conj is an underspecified functional head whose categorial feature is fixed by its conjuncts (Gazdar et al. 1985 a.o.), as in $(15)^{8}$, where $\mathrm{Y}(\mathrm{P})$ categorially equals $\mathrm{X}(\mathrm{P})$ in balanced coordination (Johannessen 1998) ${ }^{9}$.

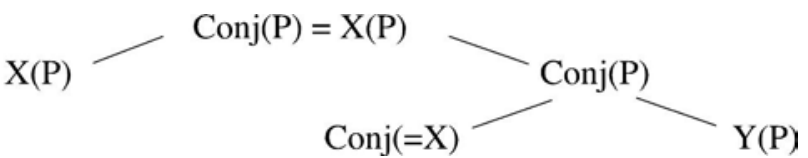

The categorial value of Conj results from Agree, an operation that matches non-distinct features: the underspecified categorial value of Conj matches and is fixed by the categorial value of one of its conjuncts, in (15), its specifier. ${ }^{10}$ Thus, ConjP is understood as a segment of $\mathrm{X}(\mathrm{P})$. Hence, not only the specifier $\mathrm{X}(\mathrm{P})$, but also an outermost element in $\mathrm{X}(\mathrm{P})$, WP, will c-command the second conjunct, accepting the c-command definition of Kayne (1994) in terms of categories, not segments of categories, see (16). ${ }^{11}$

(16) $[\mathrm{Conj}(\mathrm{P})=\mathrm{X}(\mathrm{P})[\mathrm{X}(\mathrm{P}) \mathrm{W}(\mathrm{P}) \ldots \mathrm{X} \ldots][\mathrm{Conj}(=\mathrm{X}) \mathrm{Y}(\mathrm{P})]]$

\footnotetext{
${ }^{7}$ The instantiation of Conj with the commitative conjunction, com 'with' in Portuguese, which selects only DPs, is an exception to this pattern of behaviour (see Colaço 2005).

${ }^{8}$ According to the Inclusiveness Condition (Chomsky 2004, 2005) - which states that syntactic mappings do not introduce any new element and only rearrange those in the domain - phrase structure observes the Bare Phrase Structure hypothesis. So, in (15) there is no bar-notation or any radical distinction between a head and its maximal projection.

9 Johannessen only considers integrated coordination. She distinguishes between two types of structures: balanced coordination, which involves conjuncts with the same features, as in (i), and unbalanced coordination, which includes constituents presenting different features, as in (ii). In the latter case it is the first conjunct that apparently assigns its features to the coordinate structure.
(i) $[$ Hun og jeg] gikk til skolen.
(Olso Nowegian: Johannessen 1998: 139)

I.Nom and I.Nom walked to the.school

(ii) He says he saw [NOM John.ACC and I.NOM] last night. (cf. Quirk et al. 1985:338)

${ }^{10}$ A reviewer asks how can (15) exclude examples like (i) and (ii):

(i) *This book and across the corridor is very nice

(ii) *On the wall and that the earth is flat is/are surprising.

From a categorial point of view, nothing prevents these examples. However, some condition must be conceived to state that the conjuncts must be parallel in grammatical relation and thematic role.

${ }^{11} \mathrm{C}$-command: $\mathrm{X}$ c-commands $\mathrm{Y}$ iff $\mathrm{X}$ and $\mathrm{Y}$ are categories and $\mathrm{X}$ excludes $\mathrm{Y}$ and every category that dominates X dominates Y. (Kayne 1994:18).
} 
In this framework the scope and binding effects in (5a), (8a) and (10a) above, can be accounted for straightforwardly. The Principle $C$ violation in (10a) is a consequence of the c-command of the first conjunct over the second one, see (17):
a. ${ }^{*} E a_{i} e \quad a$ filha da Maria $_{i}$ são
as minhas
she and the daughter of theMaria be-IDD.PRS.3.PL the my
melhores amigas.
best friends
'She and Mary's daughter are my best friends.'
b. [ConjP=DP [DP Elai $]$ [ [Conj ] [DP a filha de a Maria ${ }_{i}$ ] ] ]

The negative reading of um só amigo, 'any friend' and qualquer esforço 'any effort' in (8a), repeated in (18a), must be imputed to the scope of the negative polarity expression Nenhum irmão 'no brother': being the outermost constituent of the first conjunct, this expression c-commands over the second conjunct and sets the negative value of these underspecified polarity expressions:
a. Nenhum
irmão o procurou
ou um só amigo.
no
brother him look-IND.
$\begin{array}{lll}\text { fez } & \text { qualquer } & \text { esforço nesse sentido } \\ \text { make-IND.PST.3.SG any } & \text { effort in that sense }\end{array}$
$\begin{array}{lll}\mathrm{fez} & \text { qualquer } & \text { esforço nesse sentido } \\ \text { make-IND.PST.3.SG } & \text { any } & \text { effort in that sense }\end{array}$
'None of his brothers looked for him nor did any of his friends make any effort in that sense.'
b. [ConjP=T(P) [тР nenhum irmão o procurou] [Conj [тР um só amigo fez qualquer esforço nesse sentido] ] ]

Finally, in (8b), repeated in (19a), the bound anaphora reading of the anaphor $s i$ própria depends on the c-command of the quantified subject in the first conjunct, as shown in $(19 b)^{12}$.
a. Toda a mulher $i$ ama
every
mulher $_{i}$ ama
woman love-
confia
trust-IND. PRS.3SG

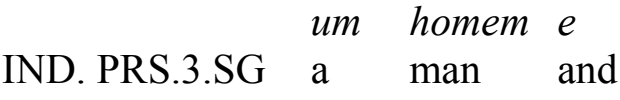
em $s i_{i}$ própria.
in herself
'Every woman loves a man and trusts herself.'
b. [ConjP(=TP)[тP Toda a mulher ama (...)] [Conj e [ _ confia em si própria $]$ ]

\footnotetext{
${ }^{12}$ The examples in (19) present Across the Board effects. The discussion of the ATB phenomenon is beyond the scope of this paper. However, as remarked in Matos (2000), correlative coordination indicates that ATB effects may occur in cases where the c-commanding constituent does not raise from its conjunct. Thus, (i) corroborates the representation proposed in (21b).
(i) Não só [toda a mulher ama
um homem][mas também[_confia em si própria]
Not only every woman love-PRS-3.SG a men but also trust-PRS.3.SG in herself
'Not only every woman loves a man but also trusts herself.' 
In sum, the possibility of accounting for scope and binding effects in integrated coordination constitutes an argument in favour of its analysis in terms of the Specifier-head-complement configuration.

\section{Pair-Merge and syntactic structure of appositive coordination}

The Adjunction hypothesis of Munn $(1992,1993)$ adequately deals with the syntactic structure of the constituents involving appositive coordination. Firstly, it accounts for the fact that the appositive and the constituent it adjoins to form a unit - as shown in (20) only this entire unit may occur in a cleft sentence.
a. Foi o João, $e$ ele é $o$ nosso be-IND.PST.3.SG the João, and he be-PRS.3SG theour melhor amigo, que não nos visitou.. best friend, who not us visit--IND.PST.3.SG 'It was John, and he is our best friend, who did not visit us.'
b. ??/*Foi o João que, e ele é be-IND.PST.3.SG the João that, and he be-IND.PRS.3SG $o$ nosso melhor amigo, não nos visitou. the our best friend, not us visit-IND.PST.3.SG. 'It was João that, and he is our best friend, did not visit us.'

Besides, it also captures that the appositive does not participate in the feature structure of the constituent that includes it - in (21), the subject counts as a firstperson singular DP, eu, as indicated by the feature agreement of the verb, adoro:

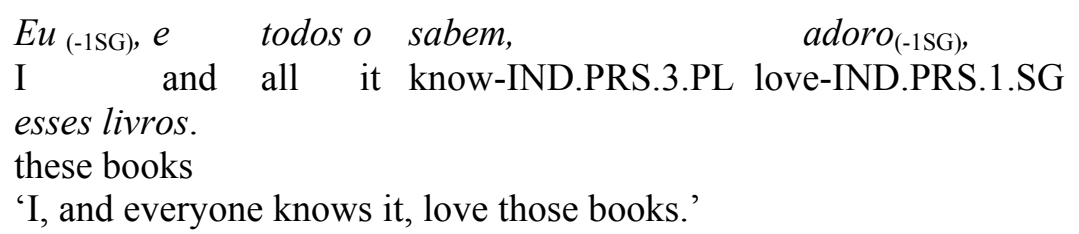

This is what we expect under the Adjunct hypothesis: in Pair Merge structures, the adjunct does not change the properties of the object it adjoins to (Chomsky $2004,2005)$ - it does not saturate its argument frame, nor does it change its categorial nature or the status of its $\varphi$-features, in (21), 1SG. See the diagram (22):

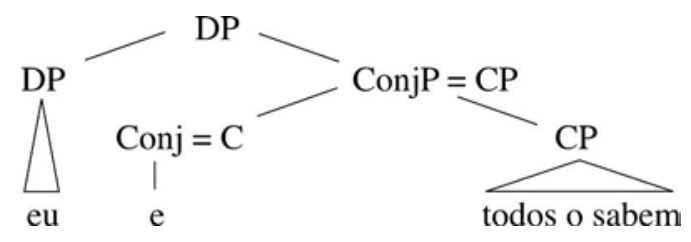

Notice that, in (22), I assume that the complement of Conj is a CP phase, i.e. a full sentential tensed domain. I also admit that in an adjunct configuration, the underspecified categorial value of Conj is fixed by the head of this complement (see 
Matos 1995), in this case C. In Minimalist terms, this amounts to saying that Conj targets $\mathrm{C}(\mathrm{P})$ in its local c-command domain, and Agree between Conj and C, sets the categorial value of ConjP as $\mathrm{CP}$.

A last argument favours the Adjunct hypothesis: if complemented by an adequate characterisation of sentence apposition, the adjunction configuration may explain the scope-blocking effects inside the appositive coordinate clause, as we will see in the next section.

\section{Appositives as parenthetical adjuncts and the blocking of c-command}

To account for the different behaviour of appositive coordination with respect to c-command, we may either posit the existence of a specific rule, or assume the usual devices of the computational system and to impute their specificity to some optional feature affecting Conj. I will take the latter approach.

As mentioned in section 1, appositive coordinate sentences behave like appositive relative clauses in blocking the scope and binding effects of a c-commanding constituent, see (23).
a. *Todo o homem, $_{i}$ e uma mulher confia nele every man, and a woman trust IND.PST.3.SG in him, está porvezes deprimido. is sometimes depressed 'Every man, and a woman trusts him, is sometimes depressed.' no brother, or a single friend make-IND.PST.3.SG any esforço nesse sentido, o procurou.
effort in that sense, him look IND.PST.3.SG for
'None of his brothers, nor any friend made any effort in that sense, looked for him.'
c. Acho que ela, e a Maria $_{i}$ é think-IND.PRS.1SG that she, and theMaria be-IND.PRS.3SG a minhamelhor amiga, é uma pessoa encantadora.
b. *Nenhum irmão, ou um só amigo fez qualquer themy best friend, be-IND.PRS.3.SG a person charming. 'I think that she, and Mary is my best friend, is a charming person.'

Given the similar behaviour of appositive relative and coordinate sentences, it is plausible to assume that they follow a general pattern of derivation. As far as relative clauses are concerned, it has been claimed that they were exempt from ccommand. Lebaux (1988) and Chomsky $(2004,2008)$ attribute this behaviour to Late Adjunction effects. Considering restrictive relatives, Lebaux (1988) claims that adjuncts, in opposition to complements, are built late in derivation; hence, they present effects at the phonological but not at the semantic interface. Under reconstruction/copy theory, this would explain the Principle $\mathrm{C}$ violation in the complement sentence in (24a), and the lack of its effects in the relative clause in (24b), examples from Lebaux (1988: 211). 
(24) a. *[Whose claim that $\mathrm{John}_{\mathrm{i}}$ likes Mary] did he $\mathrm{i}_{\mathrm{i}}$ deny $\mathrm{t}_{\mathrm{wh}}$ ?

b. [Which claim that $\mathrm{John}_{\mathrm{i}}$ made] did he $\mathrm{i}_{\mathrm{i}}$ later deny $\mathrm{t}_{\mathrm{wh}}$ ?

The main theoretical problem of this proposal is the interpretation of the adjunct at the semantic interface, in view of the $\mathrm{Y}$ schema of articulation of the computational system components in the Principles \& Parameters Theory.

In addition, as shown in Chomsky 2004, this hypothesis is also empirically problematic, since there are cases of adjunct clauses subject to Condition C, (25).

(25) $* \mathrm{He}_{\mathrm{i}}$ asked [which picture that $\mathrm{John}_{\mathrm{i}}$ liked ] Mary bought $\mathrm{t}_{\mathrm{wh}}$. (Chomsky 2004: 117)

In view of this data, Chomsky (2004) proposes that adjuncts enter the derivation by Pair-Merge, assumed as a configuration that blocks c-command from an external element, but may optionally be "simplified to Set Merge at the point of Transfer, thus permitting phonetic linearization and yielding 'late insertion' at the semantic interface.'(Chomsky 2008:147).

Yet, examples like (25) challenge the idea that the blocking of c-command is a consequence of the adjunction configuration alone, and raise the hypothesis that some additional property is involved in the systematic lack of scope and binding effects in appositive sentences.

In fact, appositive relative and coordinate sentences share a major property: they are parenthetical clauses. ${ }^{13}$ This status is evident in languages like Portuguese, where appositive sentences may present a specific intonation pattern and be separated from the nominal expression they modify by an intonation rupture, represented in writing by commas, see (4), repeated in (26):

$\begin{array}{llll}\text { a. } O \text { Pedro, que dorme } & \text { muito pouco, nunca } \\ \text { the Pedro, who sleep-IND.PRS.3.SG very little, } & \text { never } \\ \text { está } & \text { cansado } & \\ \text { be-IND.PRS.3SG tired } & \end{array}$

'Pedro, who hardly sleeps, is never tired.'
b. $O$ Pedro, e ele dorme muito pouco, nunca
The Pedro, and he sleep-IND.PRS.3SG very little, never está cansado.
be-IND.PRS.3SG tired

'Pedro, and he hardly sleeps, is never tired.'

\footnotetext{
13 Much of the literature focused on sentential parentheticals (Quirk et al. 1985, Rooryck 2001, Altshuler \& Déprez 2006); Yet, some authors admit that parentheticals may present a different categorial nature (eg.. McCawley 1982, Emonds 1979). I will not pursue this discussion here, since it would imply a full analysis of parentheticals, which is beyond the scope of this article.
} 
Thus, I assume that the crucial factor that blocks binding and scope effects of a c-commanding constituent external to the appositive clause is its parenthetical nature. This parenthetical status is taken by the computational system as a clue for the autonomy of the appositive clause with respect to the constituent it adjoins to and the sentence in which it is embedded, at the levels of phonological and semantic interface. The question now is to explain how this information is made available to the computational system, in order to derive the right outputs.

Yet, two core properties of appositive sentences may have counterparts in the Lexicon and in Syntax. First, the parenthetical status of an appositive sentence may be codified in its head by the feature [+ parenthetical]. ${ }^{14}$ The choice of this optional feature will lead the computational system to interpret the constituent as a comment running in parallel with the sentential content of the including clause. Second, the relative autonomy of the appositive results from its completeness as a full sentential CP-phase, and its grammatical relation as an adjunct. ${ }^{15}$

Given the characterization of sentence apposition presented, and adopting the Minimalist framework, it is possible to explain the blocking of c-command effects inside the appositive adjunct. The derivation of (27) illustrates this claim.

$\begin{array}{lll}\text { Ela } a_{i} \text { e a } & \text { Maria }_{i} \text { trabalha } & \text { muito, arranja } \\ \text { she, and the } & \text { Maria work-IND.PRS.3.SG } & \text { hard, get-IND.PRS.3.SG } \\ \text { sempre tempo para os amigos. } & \\ \text { always time for the friends. } & \end{array}$

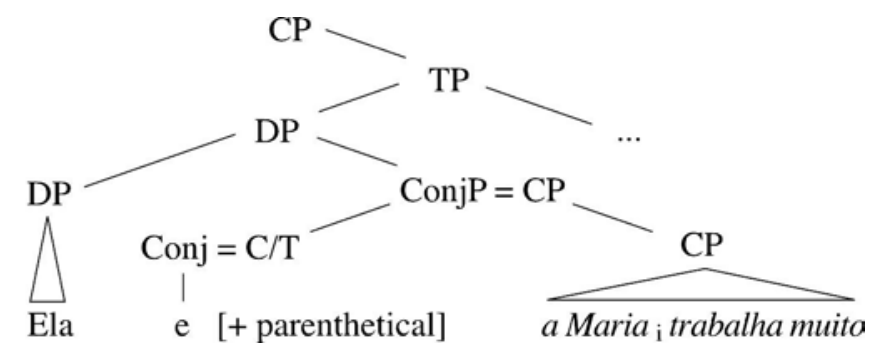

\footnotetext{
${ }^{14}$ For other kinds of parentheticals see Rooryck (2001), who excludes from his analysis appositive relative and coordinate sentences. He deals with parentheticals in terms of evidentiality, a notion proposed in Chafe and Nichols (1968), who claim that it applies to "the grammatical categories that indicate how and to what extent the speaker is engaged with the truth of what he says".

${ }^{15}$ Within the framework of generative grammar, several authors have tried to structurally capture the autonomy of the content of the including sentence with respect to the one of the appositive sentence (e.g., Ross 1967, Emonds 1979, Huddlestone et al. 2002, De Vries 2005). Huddlestone et al 2002, for instance, admit that that a supplement is semantically related to a constituent (its anchor) but constitutes a syntactically independent expression. I do not adopt this view, considering the arguments for analysing the appositive and phrase it is apposed to as a syntactic constituent (section 4). Recent studies on parenthetical constructions also show that they form a constituent with the expression they are related to, e.g. Potts 2002, for 'as parentheticals', and Altshuler \& Déprez (2007), for 'Parenthetical Null Topic Constructions'.
} 
Within the computational system, the derivation of each sentence proceeds bottom up, and Transfer applies according to an Earliness Condition (Pesetsky 1989, Chomsky $2001^{16}$ ) transferring each Phase to SEM and PHON, as soon as possible. In the case of an appositive sentence, the [+parenthetical] feature indicates that it has autonomy with respect to the constituent it adjoins to. Hence, it must be transferred to the interface levels before its modified constituent is. This one will have to wait until the next relevant phase - in (28), the root CP phase, because the modified DP is the external argument of the sentence. ${ }^{17}$

The earlier transfer of the Parenthetical Clause originates its interpretation at SEM without the presence of the constituent it modifies. This precludes the ccommanding effects of this constituent over the appositive adjunct sentence, and the consequent absence of scope and binding interpretations.

This is not so for the restrictive or non-appositive adjuncts that present less autonomy with respect to the adjoined constituent, nor for the complements in Specifier-head-complement configurations. In these cases, to obtain the intended interpretation, Transfer will be delayed until the phase that includes the adjunct, or the complement, and its c-commanding elements. ${ }^{18}$

${ }^{16}$ I take the version of the Earliness Principle presented in Chomsky 2001:15, which requires that computations be performed as soon as possible. In Chomsky 2001, this principle focus on the elimination of features under Mach; the current study considers its consequences with respect to the transfer to the interface levels.

${ }^{17}$ Since the property for the Earliness Principle to apply to appositives is the parenthetical feature, a reviewer asks how can we account for (i), which does not present anti c-command effects:

(i) I think that she, and even Marta, would be pleasantly surprised by the decision.

I would not impute this fact to a Principle $\mathrm{C}$ violation, but to the semantic nature of the coordinate DP. In (i), and even Marta is not a specifying coordination: the non-integrated DP does not share referential identity with, nor is a definer of, the related DP.

${ }^{18}$ A reviewer asked if the parenthetical feature would not be enough to account for the earlier transfer of appositives, while keeping that they are specifier-head-complement structures. I believe that the status of appositives as adjuncts is required. The specifier-head-complement analysis would incorrectly take the appositive and the apposed constituent as arguments of Conj, as in (ii):

(i) Elas, e as raparigas trabalham muito, têm muitos amigos.

they.PL, and the girls work-IND.PRS.3.PL hard, have-IND.PRS.PL many friends.

They $_{\mathrm{i}}$, and the girls are hard workers, have many friends.'

(ii) $\left[\right.$ ConjP=DP.3PL [D Elas. 3PL] [[Conj=D and ] [CP $\left.\left.\mathrm{CParenthetical}_{\text {+ }}\right]\right]$ ] têm.3.PL (...)

In (ii), Conj assumes the categorial nature of its specifier and the whole coordinate structure counts as a DP.3PL, as shown by verb agreement in the root sentence. Thus, the $[+$ parenthetical] feature would plausibly be assigned to the CP complement of Conj. Since Transfer applies as soon as possible to autonomous phases, this $\mathrm{CP}$ complement would be sent to the interface levels leaving behind the specifier of ConjP and the stranded conjunction ([DP [Conj] ). In other words, it would be impossible to say that whole coordinate structure constitutes the parenthetical constituent. However, this is possible, adopting the adjunct analysis, since in this case the adjunct clause corresponds to the entire ConjP, with exclusion of the related DP, see (iii).

(iii) $\left[\mathrm{DP}\left[\mathrm{Conjp}_{\mathrm{P}}\right.\right.$ and $\left.\left._{+ \text {parenthetical }} \mathrm{CP}\right]\right]$. 


\section{Concluding remarks}

1. Non-appositive coordinate sentences behave differently from appositive ones, with respect to scope and binding effects of a c-commanding constituent, and present similar contrasts to those opposing restrictive to appositive relatives.

2. Adopting a Set Merge approach to integrated coordination, it is possible, in the resulting specifier-head-complement configuration, to adequately account for the scope and biding effects of the first conjunct over the second conjunct.

3. Most of the properties of appositive coordination can be captured in terms of the Adjunction hypothesis, which assumes that ConjP is Pair Merge with the connected constituent that, at first sight, constitutes the first conjunct.

4. Appositive sentences, either coordinate or relative, share the property of being parentheticals. This parenthetical nature, associated with their $\mathrm{CP}$ phase adjunct status, explains the lack of c-command effects inside the appositive clause. The [+parenthetical] feature of the head of the appositive is interpreted by the computational system as a clue for its autonomy with respect to the constituent it adjoins to. Since the derivation proceeds bottom up, and Transfer applies as early as possible, this phase is transferred to SEM before the phases it is inserted in.

\section{References}

Alexiadou, Artemis, Paul Law, André Meinunger \& Chris Wilder. 2000. "Introduction". The Syntax of Relative Clauses, ed. by Artemis Alexiadou, Paul Law, André Meinunger \& Chris Wilder, 1-51. Amsterdam \& Philadelphia: John Benjamins.

Altshuler, Daniel \& Viviane Déprez. 2007. "Parenthetical Null Topic Constructions in Romance". Current Issues in Linguistic Theory, 287. John Benjamins,

Brito, Ana M. 2005. "As Relativas Não-Restritivas com Antecedente Nominal como um Caso de Aposição". Actas do XX Encontro da Associação Portuguesa de Linguística, ed. by Inês Duarte \& Isabel Leiria, 401-419, Lisboa: APL.

Chafe, Wallace \& Johanna Nichols, 1986. Evidentiality: the Linguistic Coding Epistemology. Advances in Discourse Processes 20. Norwood, NJ: Ablex.

Chomsky, Noam. 2001. "Derivation by Phase", Ken Hale, a Life in Language, ed. by Michael Kenstowicz, 1-52, Cambridge, Mass.: MIT Press.

. 2004. "Beyond Explanatory Adequacy". Structures and Beyond - The

Cartography of Syntactic Structures, ed. by Adriana Belletti, vol. 3, 105-131.

Oxford: Oxford University Press.

2005. On Phases. Foundational Issues in Linguistic Theory - Essays in

Honor of Jean-Roger Vergnaud, edited by Robert Freidin, Carlos Otero and Maria-Luisa Zubizarreta, 133-147, Cambridge, Mass: MIT Press.

Colaço, Madalena. 2005. Configurações de Coordenação Aditiva: Tipologia, Concordância e Extracção. Tese de Doutoramento, Universidade de Lisboa. 
De Vries, Mark. 2006. “The Syntax of Appositive Relativization: On Specifying Coordination, False Free Relatives and Promotion". Linguistic Inquiry, 37:2. 229-270.

Gazdar Gerald, Ewan Klein, Geoffrey Pullum \& Ivan Sag.1985. Generalized Phrase Structure Grammar, Oxford, Basil Blackwell.

Emonds, Joseph. 1997. "Appositive Relatives Have No Properties". Linguistic Inquiry, 10:2. 211-243.

Huddlestone, Rodney, John Payne \& Peter Peterson. 2002. "Coordination and Supplementation". The Cambridge Grammar of English, ed. by Rodney Huddlestone \& Geoffrey Pullum, cap. 15. Cambridge: Cambridge University Press.

Johannessen, Janne. 1998. Coordination. Oxford: Oxford University Press.

Kayne, Richard. 1994. Asymmetric Syntax. Cambridge, Mass.: MIT Press.

Koster, Jan. 2000. Extraposition as Parallel Construal. Ms.

Lebaux, David. 1988. "Relative Clauses, Licensing and the Natures of the Derivation". Syntax and Semantics. 25. 209-239.

Matos, Gabriela. 1995. "Estruturas Binárias e Monocêntricas em Sintaxe: algumas Observações sobre a Coordenação de Projecções Máximas". Actas do X Encontro da Associação Portuguesa de Linguística, 301-315. Lisboa: APL. 2000. "Across-the-Board Clitic Placement in Romance Languages". Probus. 12:2. 229-259.

Munn, Alan. 1992. "A Null Operator Analysis of ATB Gaps". The Linguistic Review. 1-26.

. 1993. Topics on the Syntax and Semantics of Coordination, PhD. Maryland University, College Park, Maryland.

Pesetsky, David. 1989. Language Particular Processes and the Earliness Principle. Ms.

Potts, Christopher. 2002. "The Syntax and Semantic of As-Parentheticals". Natural Language \& Linguistic Theory 20. 623-689.

Quirk, Randolph, Sidney Greenbaum, Geoffrey Leech \& Jan Svartvik. 1985. A Comprehensive Grammar of the English Language. London: Longman.

Ross, John. 1967. Constraints on Variables in Syntax. PhD Dissertation, MIT. Cambridge, Massachusetts.

Rooryck, Johan. 2001. "Evidentiality”, Part I. Glot International, Vol. 5, No4, April, 125-133.

Safir, Ken. 1986. "Relative Clauses in a Theory of Bindings and Levels". Linguistic Inquiry, 17:4. 663-689.

Sturm, Arie. 1986. Primaire Syntactische Structuren in het Nederlands. Leiden: Martinus Nijhoff. 